\title{
PENGARUH MEROKOK PADA PEROKOK AKTIF DAN PEROKOK PASIF TERHADAP KADAR TRIGLISERIDA
}

\author{
Elsy Putri Parwati \\ STIKes Surya Mitra Husada \\ elsyputri3@gmail.com
}

\begin{abstract}
ABSTRAK
Efek merokok mengakibatkan kecanduan merokok yang terus berkembang di Indonesia, didorong beragam kecenderungan masyarakat, pendapat medis, dan temuan penelitian. Gangguan kecanduan berdasarkan tinjauan literature merokok. Kecandauan tembakau paling bermasalah di seluruh dunia dan merugikan. Efek kesehatan yang meliputi jutaan kematian dini. Melaporkan tingkat tinggi merokok mungkin tidak meningkatkan tingkat paparan toksin secara proporsional. Perokok berat mencerminkan upaya untuk mengekstrak lebih banyak nikotin dari rokok dan meningkatkan paparan toksin. Selain itu, tingkat merokok yang lebih tinggi dapat menyebabkan kerusakan fatal dan peningkatan kadar trigliserida perokok aktif daripada pasif. Dianalisis dengan fotometer pada sampel darah. Terkait dengan akumulasi konsumsi tembakau dan merokok selama bertahun-tahun dengan usia dan jenis kelamin. Dalam penelitian, paparan yang lebih tinggi dikaitkan dengan peningkatan kadar trigliserida. Menunjukkan bahwa akumulasi merokok seumur hidup dapat menyebabkan kerusakan fatal dan peningkatan trigliserida. Konsentrasi trigliserida darah adalah salah satu parameter yang paling sering digunakan dalam praktik klinis.
\end{abstract}

\section{Kata kunci : Kadar Trigliserida, Perokok aktif dan pasif}

\section{LATAR BELAKANG}

Di Indonesia aktivitas merokok sudah menjadi kebiasaan sehari-hari. Berdasarkan Peraturan Pemerintah No.109 Tahun 2012 tentang pengamanan bahan yang mengandung zat adiktif berupa produk tembakau bagi kesehatan menyatakan bahwa rokok adalah salah satu produk tembakau yang dimaksudkan untuk dibakar dan dihisap atau dihirup

Merokok merupakan salah satu faktor risiko utama yang dapat menyebabkan peningkatan penyakit kardiovaskuler melalui pengaruhnya kadar profil lipid. Rokok terdiri dari 4.000 lebih bahan kimia, salah satu unsur utamanya yaitu nikotin. Nikotin dapat meningkatkan sekresi adrenalin pada korteks adrenal yang mendorong peningkatan konsentrasi serum asam asapnya yang dihasilkan dari tanaman Nicotiana tobacum, Nicotiana rustica dan spesies lainnya atau sintetisnya yang asapnya mengandung nikotin yang bersifat adiktif dan tar bersifat karsinogenik. Volkow (2015) bahkan telah mendefiniskan bahwa kecanduan sebagai penyakit kehendak bebas. Dimana merokok merupakan perilaku sukarela yang membuat seseorang untuk melanjutkan atau tidak.

lemak bebas (Free Fatty Acid/ FFA) yang selanjutnya menstimulasi sintesis dan sekresi kolesterol hepar seperti sekresi Very Low Density Lipoprotein (VLDL) hepar yang didalamnya terdapat trigliserida, sehingga kadar trigliserida darah meningkat (Nilawati et al 2008). 
Berdasarkan penjabaran masalah dan dampak yang terjadi pada perokok, maka dilakukan penelitian mengenai distribusi perokok menurut orang, tempat, dan tingkatan serta kondisi kesehatan yang dialami perokok. Untuk kedepannya, diharapkan tingkat konsumsi rokok dapat diminimalisir dengan menanamkan kesadaran diri sendiri terhadap bahaya rokok bagi pengguna aktif dan pasif. Melakukan sosialisasi terhadap lingkungan masyarakat di berbagai kalangan mengenai dampak konsumsi rokok secara langsung maupun tidak langsung. Meningkatkan kepedulian kesehatan lingkungan mengenai bahaya asap rokok. Menjelaskan beberapa aspek perilaku merokok manusia. Memahami pentingnya fenomena bahaya nikotin, perubahan intensitas terengah-engah selama merokok satu batang rokok terkait bukan dengan kontrol serapan nikotin tetapi juga modifikasi komposisi asap rokok sebelum menghirup. Disarankan agar nikotin, selain efek utamanya, memiliki tindakan lokal untuk mengurangi respons saluran napas akut terhadap komponen iritasi asap rokok. Diharapkan memiliki implikasi baik untuk desain rokok dan rekomendasi yang diberikan pada perokok oleh badan kesehatan wajib undangundang. Memiliki implikasi yang luas untuk teori psikologis dan filosofis, formotivation. Untuk kebijakan pengobatan dan intervensi obat, untuk tugas hukum tanggung jawab dan untuk kebijakan pemerintah. Program pencegahan penargetan remaja harus berfokus pada pengurangan merokok di lingkungan sosial dan bahaya penggunaan tembakau.

\section{KASUS/ MASALAH}

Berdasarkan data yang dinyatakan oleh WHO, Indonesia merupakan Negara ketiga dengan jumlah perokok terbesar di dunia setelah cina dan india. Peningkatan konsumsi rokok berdampak pada makin tingginya beban penyakit akibat rokok dan bertambahnya angka kematian akibat rokok. Tahun 2030 diperkirakan angka kematian perokok di dunia akan mencapai 10 juta jiwa, dan $70 \%$ diantaranya berasal dari Negara berkembang. Saat ini 50\% kematian akibat rokok berada di Negara berkembang. Bila kecenderungan tetap berlangsung, sekitar 650 juta orang akan terbunuh oleh rokok, yang setengahnya berusia produktif dan mengurangi waktu hidupnya sebesar 20-25 tahun (World Blank). Menyebutkan bahwa merokok lebih dari 5 batang per hari dan lebih dari 2 tahun dapat meningkatkan kadar total kolesterol dan trigliserida.

\section{TINJAUAN PUSTAKA}

Menurut Kamus Besar Bahasa Indonesia (2005) menyatakan bahwa rokok yaitu gulungan kecil tembakau 
dengan potongan halus kira-kira sebesar kelingking yang dilapisi dengan kertas tipis atau nipah yang dirancang untuk merokok. Rokok adalah satu-satunya produk yang dijual di pasar bebas yang, bila digunakan sesuai petunjuk, bisa membunuh orang. Kata "rokok" adalah bahasa Prancis yang kecil dari "cigare" (cerutu), dari "cerutu" Spanyol. Asap rokok (CS) adalah sumber lingkungan yang signifikan dari paparan manusia terhadap jenuh aktif (acetaldehid) kimiawi dan $\alpha, \beta$ unsaturated aldehydes (acrolein) yang menginduksi karbonil dan disfungsi protein. Pemaparan jaringan oral terhadap bahaya lingkungan sangat besar, terutama pada perokok.

Faktor resiko yang ditetapkan untuk memulai merokok selama masa remaja (orang tua, saudara kandung, teman merokok, perokok di rumah atau kampus dan lingkungan sekitar tetangga, paparan merokok di mobil, kinerja akademis, kerentanan terhadap merokok, gejala depresi/strees, gelisah, kesepian, harga diri, keterhubungan pendidikan. Penggunaan produk tembakau lainnya dikaitkan dengan inisiasi di masa remaja, dan perbedaan jenis kelamin/umur. Faktor risiko terhadap interaksi inisiasi dan interaksi aditif dengan gender.

Setelah penyesuaian untuk usia, jenis kelamin dan pendidikan, semua faktor risiko kecuali kinerja akademis dan keterhubungan pendidkan secara statistik terkait dengan inisiasi.

Faktor risiko inisiasi merokok pada remaja mencerminkan pada remaja; Efeknya tidak berbeda nyata menurut jenis kelamin.

\section{Kategori perokok}

Kategori perokok secara umum dibagi menjadi dua jenis, yaitu perokok aktif dan perokok pasif. Berikut adalah penjelasan tentang kategori perokok:

\section{Perokok Aktif}

Rokok aktif adalah asap rokok yang berasal dari hisapan perokok atau asap utama pada rokok yang dihisap secara langsung. Jadi, perokok aktif merupakan seseorang yang merokok dan langsung menghisap rokok maupun menghirup asap rokoknya sehingga berdampak pada kesehatan serta lingkungan sekitar. Jadi, seorang perokok aktif merupakan individu yang memiliki kebiasaan merokok didalam hidupnya (Bustan, 1997).

\section{Perokok Pasif}

Menurut Wardoyo (1996) menyatakan bahwa perokok pasif merupakan asap rokok yang dihirup oleh seseorang yang tidak merokok(Pasive smoker). Asap rokok merupakan polutan bagi manusia dan lingkungan sekitarnya. Dinyatakan lebih berbahaya terhadap perokok pasif daripada perokok aktif. Asap rokok yang dihembuskan oleh perokok aktif dan terhirup oleh perokok pasif, lima kali lebih banyak mengandung karbon monoksida, empat kali lebih banyak mengandung tar dan nikotin.Jadi,seorang perokok pasif merupakan individu yang tidak memiliki kebiasaan merokok, tetapi harus menghirup asap rokok yang 
dihembuskan oleh orang sekitarnya yang merokok.

Menurut ahli menyatakan bahwa setiap perokok dapat dibagi menjadi beberapa tingkatan tergantung pada jumlah rokok yang dikonsumsi(Rosmawati, 2010). Berikut adalah tingkatan jenis perokok:

1. Perokok ringan (1-10 batang)

2. Perokok sedang (11-20 batang)

3. Perokok berat ( $>20$ batang)

Trigliserida merupakan lemak netral. Fungsi utama trigliserida adalah sebagai zat energi. Ketika sel membutuhkan energi, enzim lipase dalam sel lemak akan memecah trigliserida menjadi gliserol dan asam lemak serta melepasnya ke dalam pembuluh darah oleh sel-sel yang membutuhkan, komponen-komponen tersebut kemudian dibakar dan menghasilkan energi, karbondioksida $\left(\mathrm{CO}_{2}\right)$, dan air $\left(\mathrm{H}_{2} \mathrm{O}\right)$ (Mustikaningrum, 2010).

\section{PEMBAHASAN}

Merokok adalah seseorang yang menggunakan rokok dan dibakar pada salah satu ujungnya dan dibiarkan membara agar asapnya dapat dihisap lewat mulut pada ujung lainnya. Didefinisikan membakar tembakau yang kemudian dihisap isinya, baik menggunakan rokok maupun menggunakan pipa.

Perokok adalah seseorang yang suka merokok disebut perokok aktif jika seseorang tersebut merokok secara aktif, dan disebut perokok pasif jika seseorang tersebut hanya menerima asap rokok sehingga terhirup tetapi bukan melakukan aktivitas merokok sendiri.

Menurut peneliti merokok dapat menyebabkan berbagai masalah dalam kesehatan karena kandungan rokok yang memiliki berbagai macam zat yang dapat merusak metabolisme tubuh yang memicu timbulnya penyakit. Gangguan metabolisme tubuh yang timbul salah satunya adalah kerusakan profil lipid oleh zat rokok yang diserap oleh tubuh.

Dampak Merokok:

Asap rokok terdiri dari berbagai bahan kimia yang beracun, antara lain karbon monoksida (CO) yang dihasilkan oleh asap rokok dan dapat menyebabkan pembuluh darah konstriksi, sehingga tekanan darah naik, dinding pembuluh darah dapat robek. Merokok menyebabkan peningkatan konsentrasi trigliserida yang diakibatkan oleh paparan karbon monoksida. Peningkatan Tg pada perokok lebih tinggi daripada bukan perokok kadar trigliserida secara signifikan lebih tinggi untuk perokok aktif daripada perokok pasif.

Produksi industri dan bentuk kertas gulung. Zat beracun pada rokok menyebabkan kerusakan organ berbeda di tubuh. Merokok memiliki pengaruh yang signifikan terhadap tingkat konsentrasi trigliserida. Merokok merupakan salah satu faktor penting yang harus diperhatikan dalam memperkirakan kadar trigliserida. Asap rokok mengandung nikotin, nitrogen oksida, karbon monoksida, hidrogen sianida dan radikal bebas yang merupakan zat beracun dan senyawa karsinogenik yang berbahaya bagi kesehatan manusia. 


\section{KESIMPULAN}

Pemerhatian khusus yang mampu meningkatkan pengembangan ilmu pengetahuan dan pemahaman mengenai dampak rokok serta akibat yang ditimbulkan akibat merokok secara langsung maupun tidak langsung.

Dapat memperluas wawasan ilmu pengetahuan tentang bahaya merokok khususnya bagi instuisi terkait dapat memberikan konstribusi untuk pelaksanaan pemeriksaan penelitian selanjutnya.

$$
\text { Menjadi informasi bagi }
$$

mahasiwa/ masyarakat untuk lebih berhati-hati dalam merokok secara langsung maupun tidak langsung, karena resiko penyakit yang ditimbulkan sangat fatal. Penelitian ini dapat diinformasikan kepada mahasiswa/ masyarakat tentang bahaya merokok terhadap trigliserida dan resiko penyakit yang ditimbulkan. Dapat memberikan informasi yang berguna mengenai efek merokok terhadap hasil kesehatan.

\section{DAFTAR PUSTAKA}

Al Annas, S. N. N., Indasah, I., Yudhana, A., \& Sodik, M. A. (2018). Analysis of Using Basic Material and Process on Organoleptic Result of Tempe Chips in Ngantru Trenggalek. Indonesian Journal of Nutritional Epidemiology and Reproductive, 1(1), 46-55.

Attoriq, S., \& Sodik, M. A. (2018). PENCEGAHAN

DAN PENGENDALIAN INFEKSI TERKAIT PELAYANAN KESEHATAN DI LAHAN PRAKTIK.

Bustan,M.N, 1997. Epidemiologi Penyakit Tidak Menular. Jakarta: Rineka Cipta
Mustikaningrum, S 2010, Perbedaan

Kadar Trigliserida Darah pada Perokok dan Bukan Perokok, Fakultas Kedokteran Universita Sebelas Maret, Surakarta.

Peraturan Pemerintah No.109 Tahun 2012 tentang Pengaman Bahan yang Mengandung Zat Adiktif berupa Tembakau bagi Kesehatan

Rosmawati.2010. Analisa Faktor-Faktor yang Berhubungan dengan Perilaku Merokok pada Remaja STM Triguna Utama Ciputat Tangerang Selatan. Jakarta:Universitas Islam Syarif Hidayatulloh

Sodik, M. A. (2018). Merokok \& Bahayanya.

Sodik, M. A., \& Nzilibili, S. M. M. (2017). The Role Of Health Promotion And Family Support With Attitude Of Couples Childbearing Age In Following Family Planning Program In Health. Journal of Global Research in Public Health, 2(2), 82-89.

Sodik, M. A., Suprapto, S. I., \& Pangesti, D. (2013). Faktor-Faktor Yang Berhubungan Dengan Pelaksanaan Pelayanan Prima Pegawai Di Rsui Orpeha Tulungagung. STRADA Jurnal Ilmiah Kesehatan, 2(1), 2432.

Tule, A. R., Siyoto, S., Dwianggimawati, M. S., \& Sodik, M. A. (2018). The Analysis Factors Affecting Interest in Medication of Receipt Help Aid BPJS Participant in Balowerti Public Health Center Kediri City. Journal of Global Research in Public Health, 3(1), 68-75.

Volkow,N.2015.Addiction is a disease of free will(http://www.drugbuse.gov/a bout-nida/norasblog/2015/06/addiction-diseasefree-will dikutip pada 5 Desember 2018 jam 09.00 WIB) 
Wardoyo,S.T.H. 1996. Bahaya Benefits of Smoking Perokok Pasif. Bandung: Departement Kesehatan

WHO.2008. "Tobacco epidemic". Report on the global.

Cessation(http://www.who.int/tobac co/quitting/en_tfi_quitting_fact_she et.pdf dikutip pada 5 Desember 2108 jam 07.00 WIB)

WHO.Tt. Fact Sheet about Health 
